\title{
LAKE ICE INVESTIGATION AT PETERS LAKE, ALASKA*
}

\author{
By Jiro Muguruma and Katsuhiro Kikuchi \\ (Faculty of Science, Hokkaido University, Sapporo, Japan)
}

\begin{abstract}
In this paper a study of lake ice at Peters Lake with respect to crystallographic nature and impurity in crystal grain boundaries is described. The appearance of the ice structure in 1962 was quite uniform over the whole area of the lake; it showed predominantly horizontal $c$-axes. Another type of ice with predominantly vertical $c$-axes could not be found even in the surface layer of the ice. The cause of these two types of ice is explained as being due to wind action. A correlation between the grain-size and the depth of ice is expressed in exponential form down to a depth of $100 \mathrm{~cm}$. A linear relationship between the thickness of ice and the depth of snow cover was obtained. Impurity in grain boundaries measured as specific electrical conductivity was hard to detect in such a pure ice as that at the lake whose purity was about $1 \mathrm{micromho} / \mathrm{cm}$. Supplementary data from Lake Nukabira, Hokkaido, are summarized and compared with the data from
Peters Lake.
\end{abstract}

RÉsumé. Ce papier présente l'étude de la glace de lac (Peters Lake) en ce qui concerne la nature cristallographique et les impuretés aux limites des cristaux. L'aspect de la structure de la glace en 1962 était pratiquement uniforme sur la surface entière du lac, avec une prédominance d'axes $c$ horizontaux. Il n'a pas été possible de trouver un autre type de glace avec des axes $c$ orientés verticalement, même dans le niveau de surface de la glace. On explique l'existence de ces deux types de glace par l'action du vent. La corrélation entre la grosseur des grains et la profondeur de la glace est exprimée sous forme exponentielle jusqu'à une profondeur de $100 \mathrm{~cm}$. On a obtenu une relation linéaire entre les épaisseurs de la glace et de la couverture de neige. La mesure de la conductivité électrique spécifique permet difficilement de détecter les impuretès aux limites des grains dans une glace aussi pure, puisque celle-ci est d'environ $\mathrm{I}$ micromho/cm. Les données complémentaires provenant du lac Nukabira, Hokkaido, sont résumées et comparées avec les données du
lac Peters.

Zusammenfassung. Die Arbeit enthält eine Beschreibung von Studien über die Kristallstruktur und die Verunreinigung an den Grenzen der Kristallkörner, angestellt an Eisproben des Peters-Sees. Das Eis zeigte im Jahre 1962 auf dem ganzen See eine sehr einheitliche Struktur mit vorwiegend horizontalen $c$-Achsen. Ein zweiter Eistyp mit vorwiegend vertikalen $c$-Achsen konnte nicht einmal in der Oberflächenschicht des Eises gefunden werden. Die Ausbildung dieser beiden Eistypen wird auf Windeinwirkungen zurückgeführt. Die Beziehung zwischen der Korngrösse und der Tiefe des Eises lässt sich bis zu einer Tiefe von $100 \mathrm{~cm}$ durch eine Exponentialfunktion darstellen. Zwischen der Eisdicke und der Höhe der Schneedecke wurde eine lineare Beziehung gefunden. Verunreinigungen an den Korngrenzen konnten durch Messung der spezifischen elektrischen Leitfähigkeit in einem so reinen Eis wie dem dieses Sees, dessen Reinheit ca. I micromho/cm erreicht, kaum festgestellt werden. Ergänzende Daten vom Nukabira-See auf Hokkaido werden zusammengefasst und mit denen vom Peters-See verglichen.

\section{INTRODUCTION}

It is well known that lake ice is generally composed of characteristic columnar crystals and usually displays a candle-like structure when it begins to melt in the spring. In this state it is called candle ice, and it is very useful when a large amount of ice is needed, because ice with this structure is easy to crush.

It was suggested by Nakaya ( 1959) that a piece of candle ice may not be a single crystal, but may be composed of many crystals. He pointed out that the boundaries between crystals of a single candle might be different in nature from the boundaries between adjacent candles, and that the latter boundaries might be much more easily melted by radiation than the former ones. The former boundaries might be called sub-boundaries, or small-angle boundaries as was suggested for lake ice (Knight, I962) and for the ice of ice island T-3 (Muguruma and Higuchi, I 963 ). One purpose of the present study is to clarify the nature of such different kinds of crystal boundaries with respect to impurity content in the boundary.

The peculiar appearance of the ice at Peters Lake was reported by Barnes (1959) and Knight (1962); two types of ice with predominantly vertical and horizontal $c$-axes were

* The research reported in this paper was supported financially by the Arctic Institute of North America under contract AF $19(604)-7403$ with Geophysics Research Directorate, U.S. Air Force Cambridge Research
Laboratories. 
observed in two distinct areas of the lake. It was shown by an aerial photograph that the former ice was white while the latter was darker. The crystallographic orientation could also be determined at a glance at an early stage of the melt season. This interesting fact stimulated the authors to try to clarify the cause of these two types of ice and to investigate the differences in their decay with particular emphasis on their physical properties.

Field investigation of the ice at Peters Lake was undertaken within the months of March and April i 962 . Unfortunately, the two types of ice pointed out by Barnes (1959) and Knight ( 1962 ) were not found during that period. Although this curtailed the research programme, the difference in ice conditions between 1962 and the previous years suggested some ideas as to the cause of the two types of ice.

Before the field work was done at Peters Lake, a tentative investigation on lake ice was made at Lake Nukabira, Hokkaido, in January 1962 when experimental equipment was being tested. The data obtained at Lake Nukabira were helpful in understanding the appearance of the ice at Peters Lake; accordingly the observations are compared with each other.

\section{Description and Auxiliary Data}

Peters Lake is located at lat. $69^{\circ} \mathrm{N}$. and long. $145^{\circ} \mathrm{W}$. in north-eastern Alaska. The lake lies wholly within a narrow glaciated valley, whose steep sides rise sharply from the water. The direction of the deep valley is such that winds blow either from the north or south (Fig. I).

Water temperature was measured weekly by lowering a thermistor at one site (site 35 in Figure I) in the deepest part of the lake. Figure 2 shows the temperature profiles. The water temperature was $0^{\circ} \mathrm{C}$. in the surface layer and about $3^{\circ} \mathrm{C}$. at the bottom of the lake at a depth of about $45 \mathrm{~m}$. There was no great variation throughout the period, but towards the end of the period there was a slight increase below io $\mathrm{m}$. depth. Though the lake water was fairly stable during the season, the formation of an unstable water layer could be noticed between the water layers of $5 \mathrm{~m}$. and $\mathrm{io} \mathrm{m}$. depth.

Ice temperature was also measured daily at one site (site 2 in Figure I) by means of thermistors whose cables were frozen into the ice. The thickness of ice at this site was $142 \mathrm{~cm}$., so the three depths of 50,100 and $130 \mathrm{~cm}$. were chosen for the measurements. Ice temperature showed a tendency to increase at all depths in the ice towards the end of occupancy of the site (Fig. 3). The phase lag of the curve for $50 \mathrm{~cm}$. depth compared with that for $100 \mathrm{~cm}$. depth is clearly seen to be one day (Fig. 3). The fact that the temperature at a depth of $130 \mathrm{~cm}$. was above $0^{\circ}$ C. seems to have been due to malfunction of the thermistor.

Ice samples were obtained either with a $3 \mathrm{in}$. $(7 \cdot 6 \mathrm{~cm}$.) diameter corer or by sawing out cubes with about $30 \mathrm{~cm}$. sides. Samples were taken at 45 sites on Peters Lake covering the whole area of the lake (Fig. I). Core drilling through the entire thickness of the ice was carried out at 20 sites and drilling down to I $\mathrm{m}$. depth was done at 23 sites. Surface ice samples, obtained by sawing blocks of ice, were taken at I I sites. At Schrader Lake, which is at the northern end of the valley, core samples were taken at 2 sites in order to ascertain whether there was any difference in ice structure from that at Peters Lake.

\section{ICE Thickness}

The thickness of ice and the depth of snow cover were measured at 20 sites each week. The increase of ice thickness was also measured weekly at 3 sites (sites 3 I, 35 and 34 in Figure I); these points represented typical locations of different ice thicknesses on the lake. The average ice thickness was about $150 \mathrm{~cm}$. at the end of March for both Peters and Schrader Lakes. The thickness varied considerably over the lake surface and a difference of about $50 \mathrm{~cm}$. was observed. The thickest ice measured was $172 \mathrm{~cm}$. at site 34 in Figure I ; the thinnest ice was $123 \mathrm{~cm}$. at site 25 in Figure I. The variation in thickness can be explained by the 
differences in snow cover or exposure to wind. As shown in Figure 4, there is a good correlation between the ice thickness and the depth of snow cover. The area along the eastern side of the lake, particularly in the area to the north of the camp (area " $\mathrm{B}$ " in Figure 5), had comparatively less snow cover and thick ice. On the other hand, the west coast area in the central part

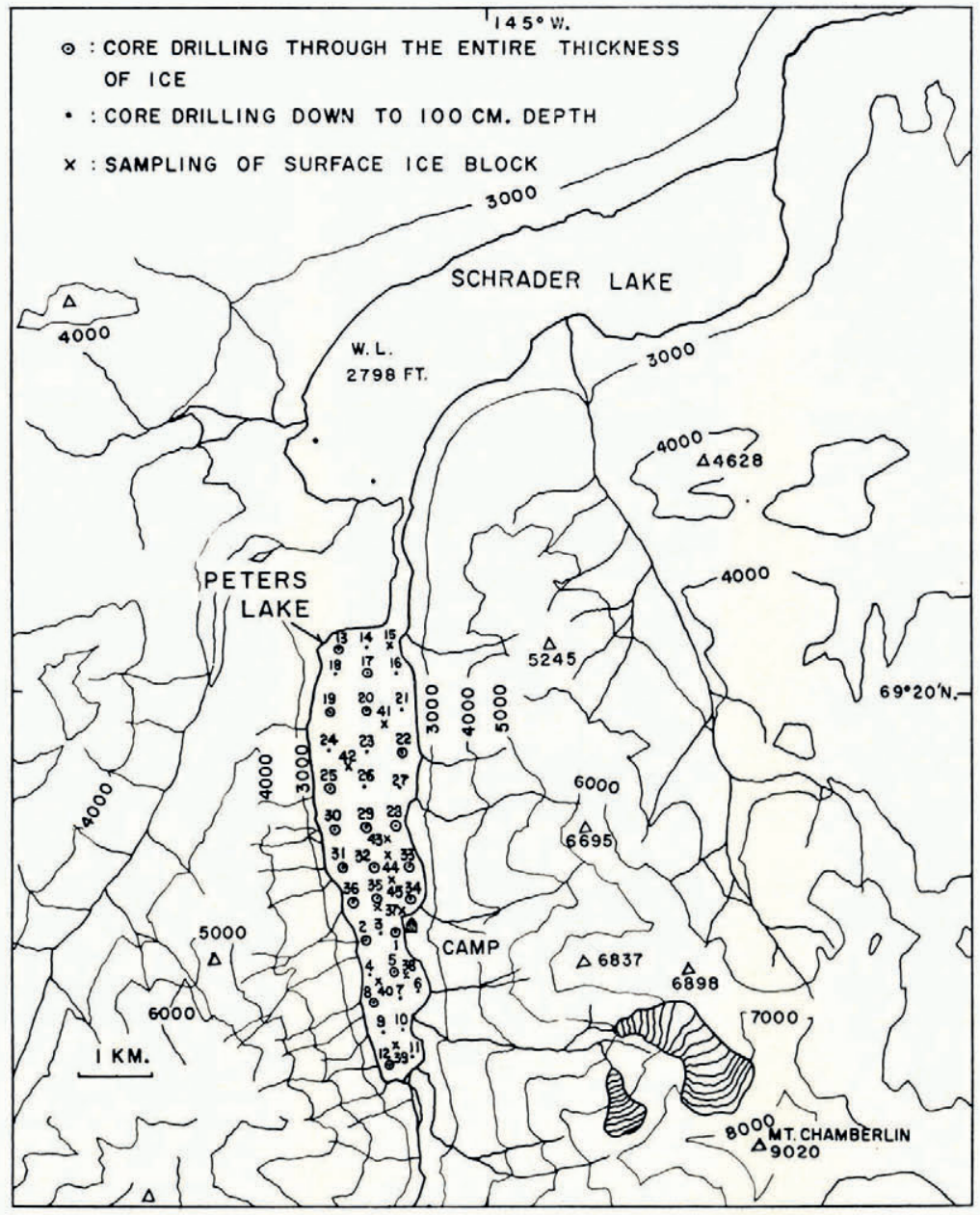

Fig. I. Map of Peters Lake showing locations where ice samples were obtained

of the lake (area "A" in Figure 5) had a thick snow cover and thin ice. The increase of ice thickness was about $0.5 \mathrm{~cm}$./day. Because of the short period of observation, it was impossible to detect the difference of increase of ice thickness depending upon the location. Before the end of the field work there was no sign of melting in the snow and ice.

\section{IGe Structure}

The size and the $c$-axis orientation of the ice crystals were studied by means of rubbings of etched ice surfaces, by the use of polarized light and by observing Tyndall figures produced with artificial radiation. Vertical and horizontal cross-sections of the samples photographed in polarized light were prepared in such a way as to be sufficiently thin to allow light to pass without giving interference colours. The crystal grains observed were predominantly columnar 


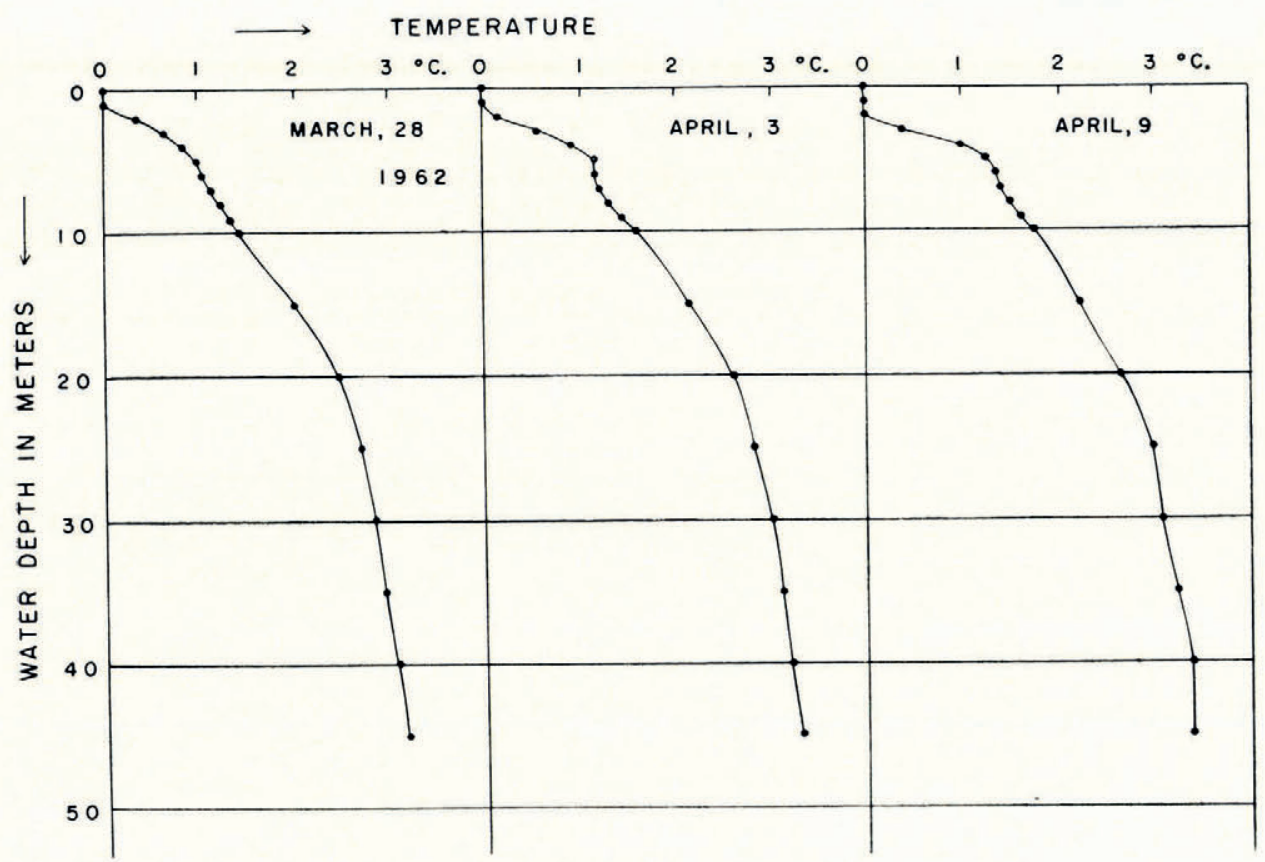

Fig. 2. Profiles of water temperature

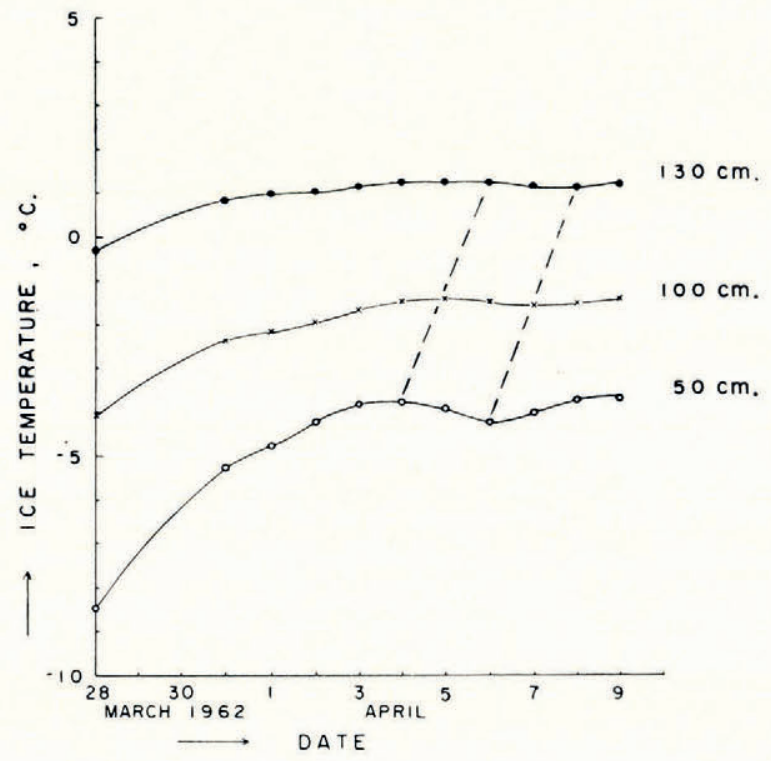

Fig. 3. Daily change of ice temperature 


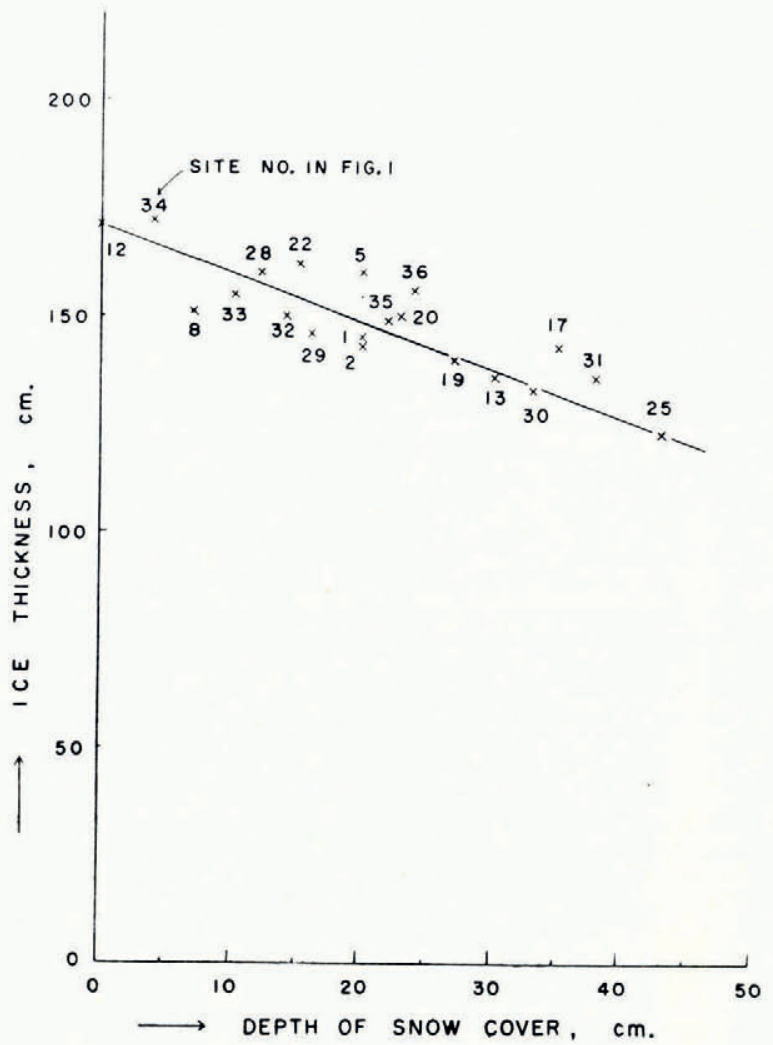

Fig. 4. Relationship between the thickness of ice and the depth of snow cover

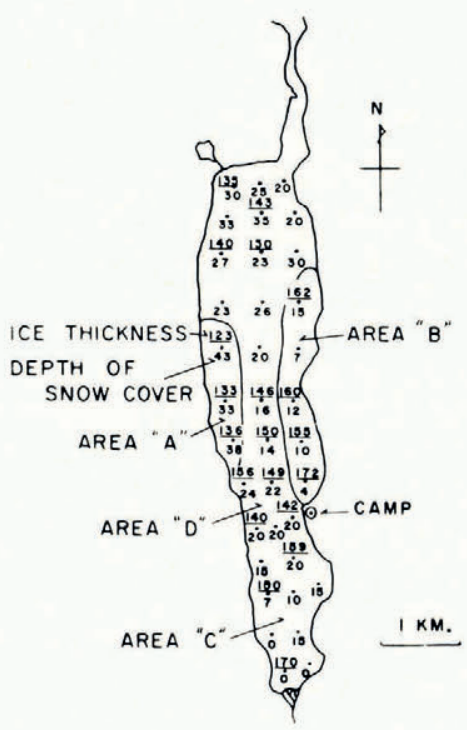

Fig. 5. Distribution of the thickness of ice and the depth of snow cover over the entire area of Peters Lake 
in shape with irregular cross-sections and nearly vertical boundaries. This is a characteristic feature of candle ice. A block of candle ice separates into component candles when exposed to solar or artificial radiation, since melting starts chiefly along the crystal boundaries. An individual candle which had been separated from the block by using the radiation from an infra-red lamp was in its entirety a single crystal. There was no difference in that feature from the candle ice observed on $\mathrm{T}-3$ (Muguruma and Higuchi, I 963). Since solar radiation was not strong enough to cause internal melting of the ice during the period of study, no vertical tubules which characterize candle ice were found to separate individual crystals.

Figures 6 to 9 are photographs of typical vertical sections of ice cores at site 35. Their horizontal cross-sections at various depths are shown in Figures so to I3. These figures illustrate
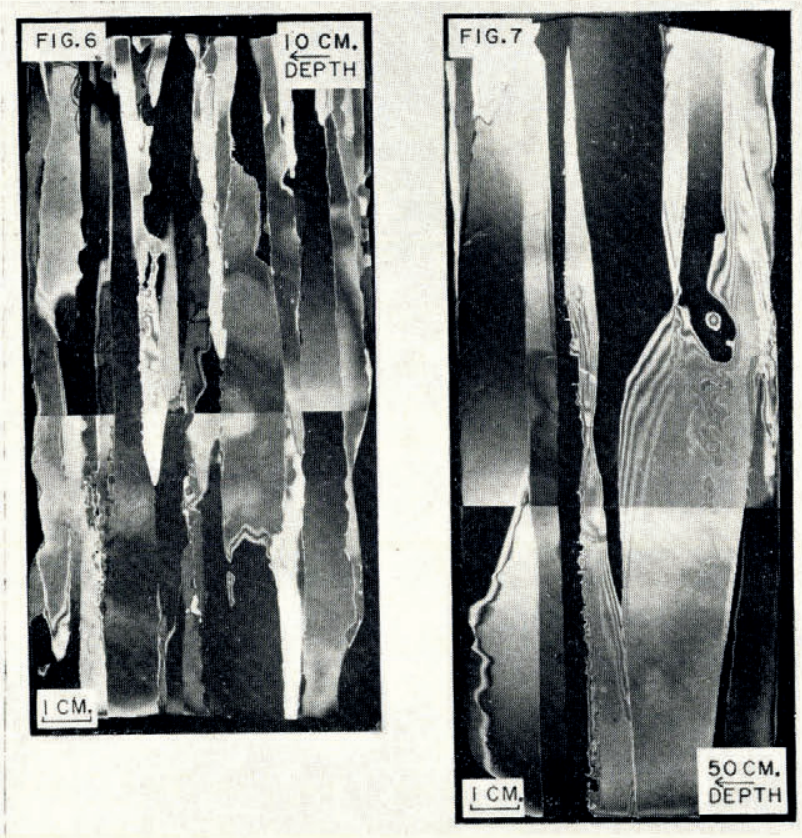

Figs. 6 and 7. Vertical sections of an ice core from site 35 ; under crossed polaroids

well the increase of grain-size with ice depth. Since the drilling crushed the surface cores, the appearance of the ice structure at the surface cannot be presented in this series of illustrations.

\section{(a) Small-angle boundary}

Very faint textures in each grain can be noticed if these photographs are examined carefully. These slight textures show the existence of small-angle boundaries which are well known in the dislocation theory of crystals. These might be called sub-boundaries, referred to by Knight ( I962).

Small-angle boundaries in ice crystals were beautifully shown by Nakaya (1958). A detailed study of the stress-induced movement of the small-angle boundaries of ice crystals was carried out by Higashi and Sakai ( $196 \mathrm{r}$ ), with an interpretation of activation energy of the movement in terms of dislocations. Indubitably the formation of such boundaries, as observed above, is due to internal strain. Considering the freezing process of lake water and its subsequent contraction at low temperatures, the formation of small-angle boundaries in lake ice would be a common phenomenon. 
The nature of a small-angle boundary is quite different from that of the boundary between adjacent crystals, because the melting starts chiefly along the boundary. The latter boundaries are expected to contain far more impurities than the former ones, which are considered to have the same impurity content as the other parts of a crystal. Though this fact is worth further investigation, in the present study it was difficult to detect such a difference.
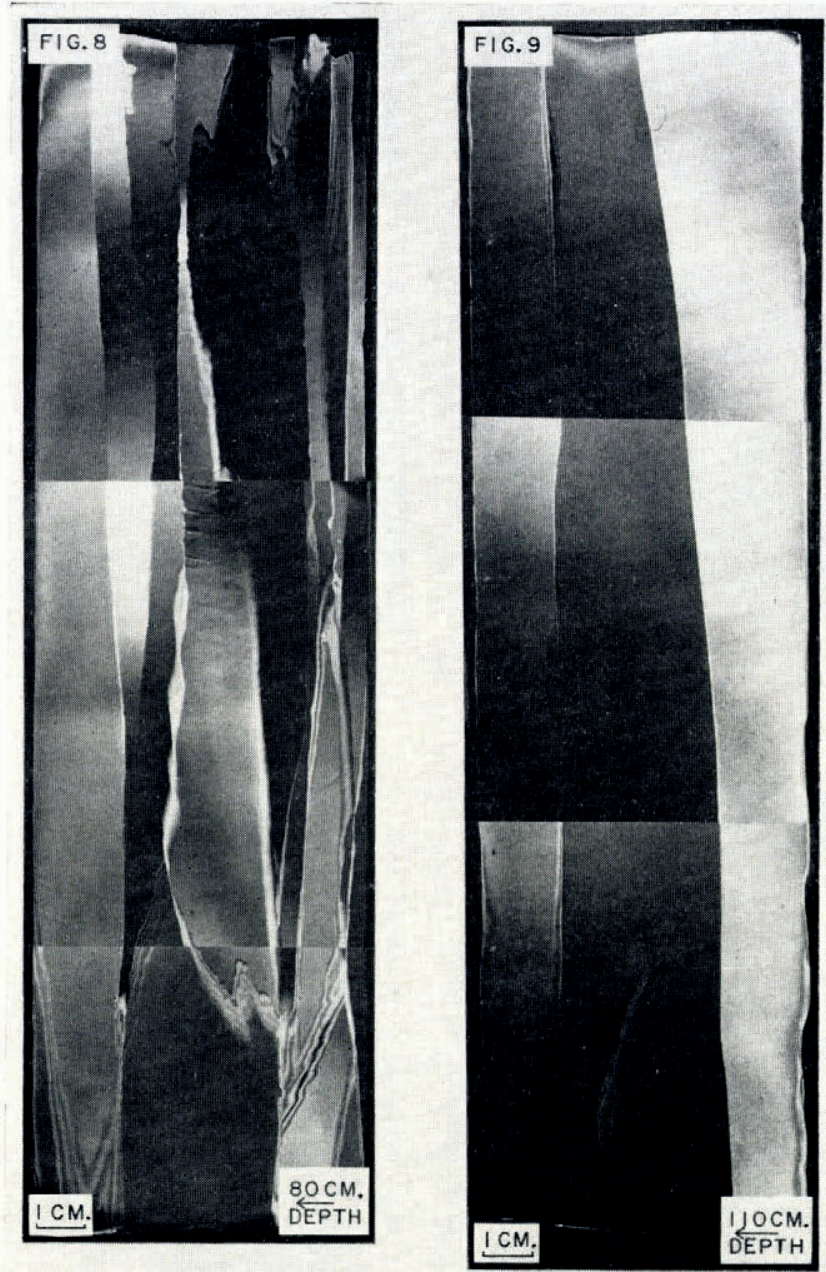

Figs. 8 and 9. Vertical sections of an ice core from site 35; under crossed polaroids

\section{(b) Orientation of the c-axis}

The orientation of crystals was studied by observing Tyndall figures produced by radiation from an infra-red lamp and by the use of polarized light. When bulk ice is exposed to this radiation, the boundaries are etched and become visible. Figures $I_{4}$ and $I_{5}$ are the prints of carbon rubbings which reveal both the size of the grains and the orientations of their $c$-axes. The numerous short bars seen in the rubbings are the marks of Tyndall figures, which show the orientation of the basal planes of the crystals if they are normal to vertical or horizontal sections. The clear prints of minute hexagonal figures seen on the right-hand side of the rubbing from site 19 in Figure 14 are also Tyndall figures showing completely horizontal 

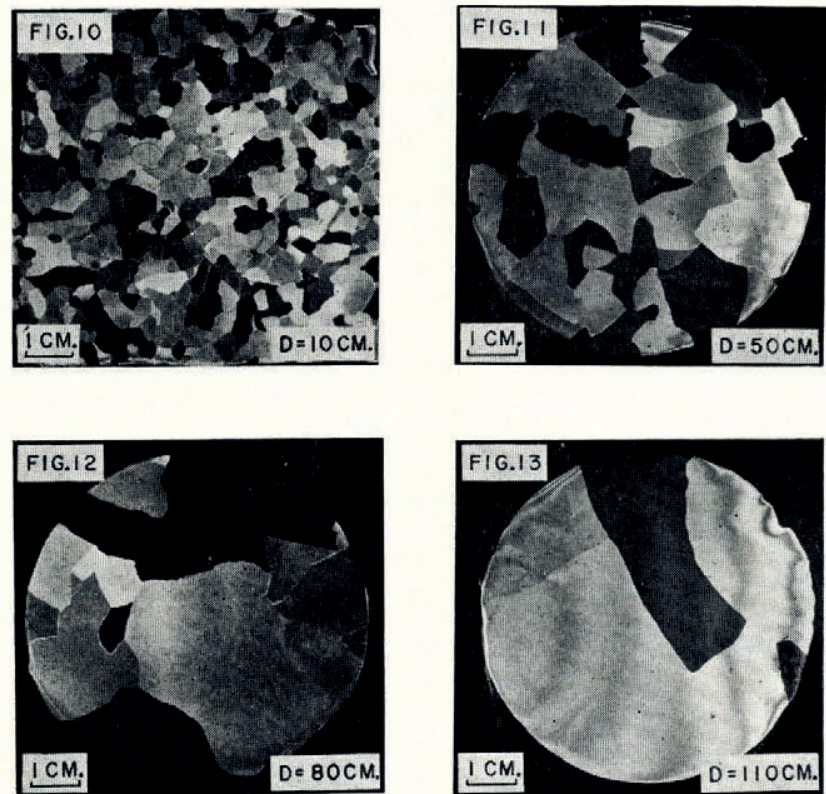

Figs. Io, II I I2 and I3. Horizontal sections of a 2 ice core from site 35 at various depths; under crossed polaroids

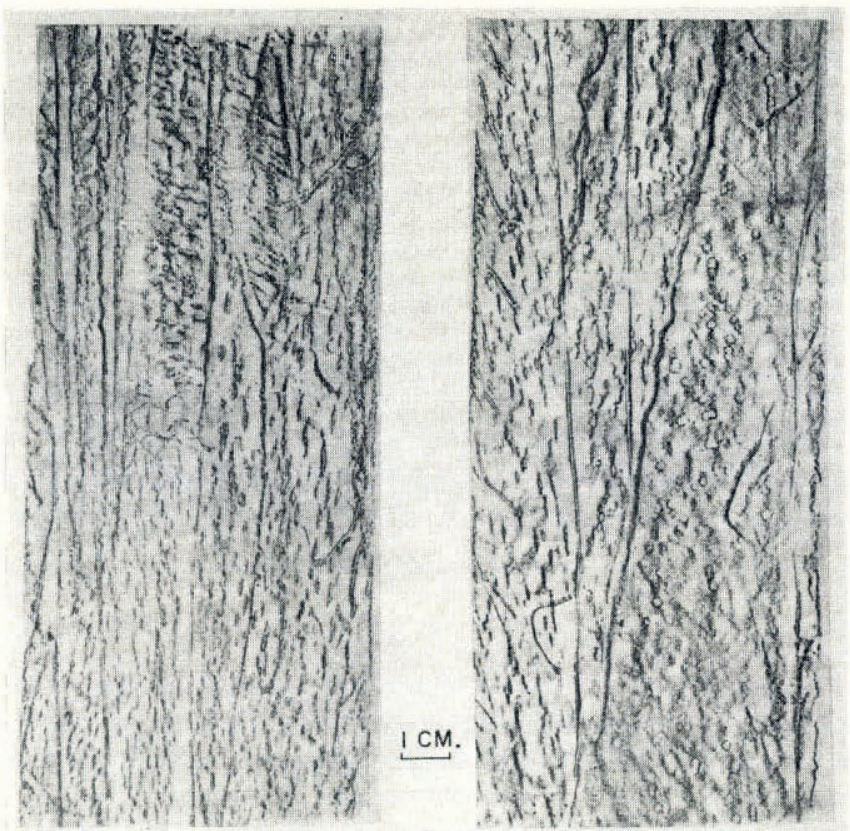

Fig. I4. Carbon rubbings of vertical sections of ice cores at $100 \mathrm{~cm}$. depth from sites 2 and I9, Peters Lake, showing grain. boundaries and Tyndall figures 
$c$-axes. Two grains in the upper part of the rubbing at site 2 in Figure I 4 show nearly vertical $c$-axes. This is an exceptional case. As far as the core samples obtained at 43 sites are concerned, all of the crystals below $30 \mathrm{~cm}$. depth had their $c$-axes predominantly horizontal. Knight (1962) reported in I96 I that about half the surface ice above $60 \mathrm{~cm}$. depth on Peters Lake was orientated with the $c$-axes vertical and the other half horizontal.

The attempt to obtain surface cores down to $10 \mathrm{~cm}$. by drilling was unsuccessful, so surface ice cubes with $30 \mathrm{~cm}$. sides were taken at $\mathrm{I}$ i sites in addition to core samples in order to investigate the detailed profile of the $c$-axis orientations in the surface layer of ice. The vertical and horizontal sections of the ice in the surface layer at site 2 are shown in Figures 16 to 18.

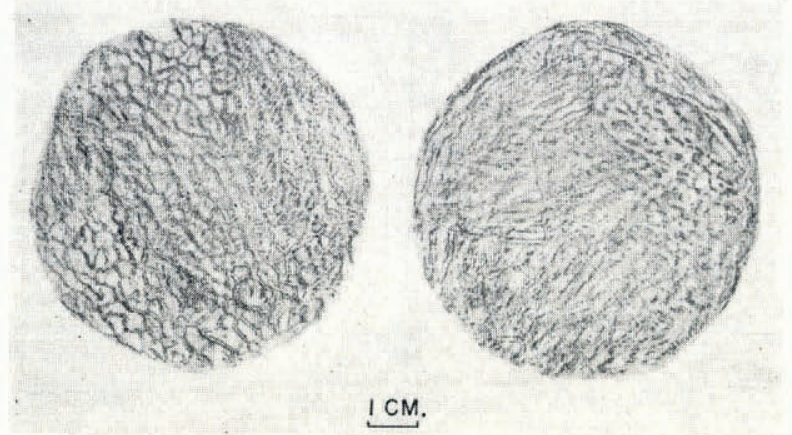

Fig. I5. Carbon rubbings of horizontal sections of an ice core at o and $133 \mathrm{~cm}$. depth from site 30 , Peters Lake, grain boundaries and Tyndall figures

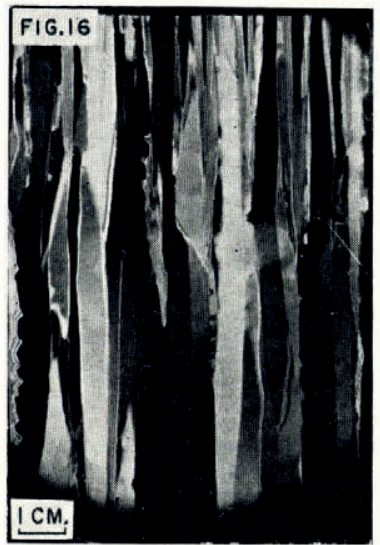

Fig. I6. Vertical section of the surface layer of ice at site 2; under crossed polaroids
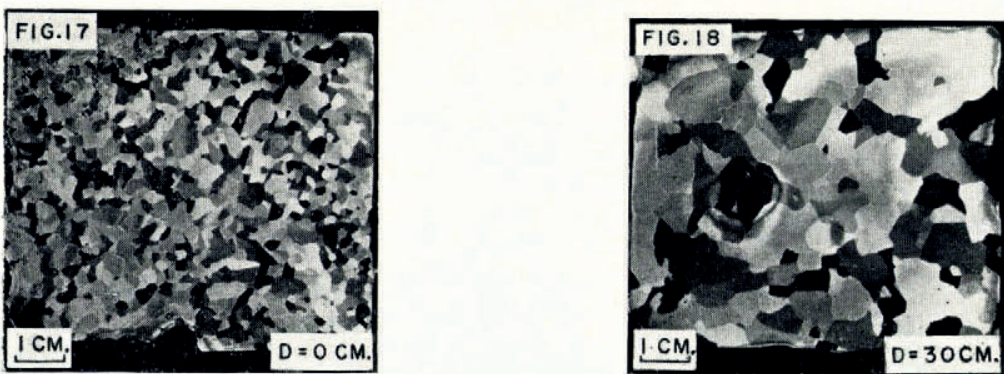

Figs. 17 and 18 . Horizontal sections of the surface layer of ice at o and $30 \mathrm{~cm}$. depths at site 2; under crossed polaroids 
The crystals have a very fine-grained appearance (compare Figures I6 and I 7 with Figures 6 and 10 ). Grain-size increases with ice depth, as is shown in these figures. In order to obtain the statistical distribution of the $c$-axis orientation, component candles were separated from a block of ice by the use of artificial radiation. A separated candle was then placed in such a way that the basal plane of the crystal was normal to the observed surface, by observing the Tyndall figures. In this way, the orientation of the $c$-axis could be determined to an accuracy of 5 degrees. Figure 19 shows four histograms for different sites giving the statistical distribution

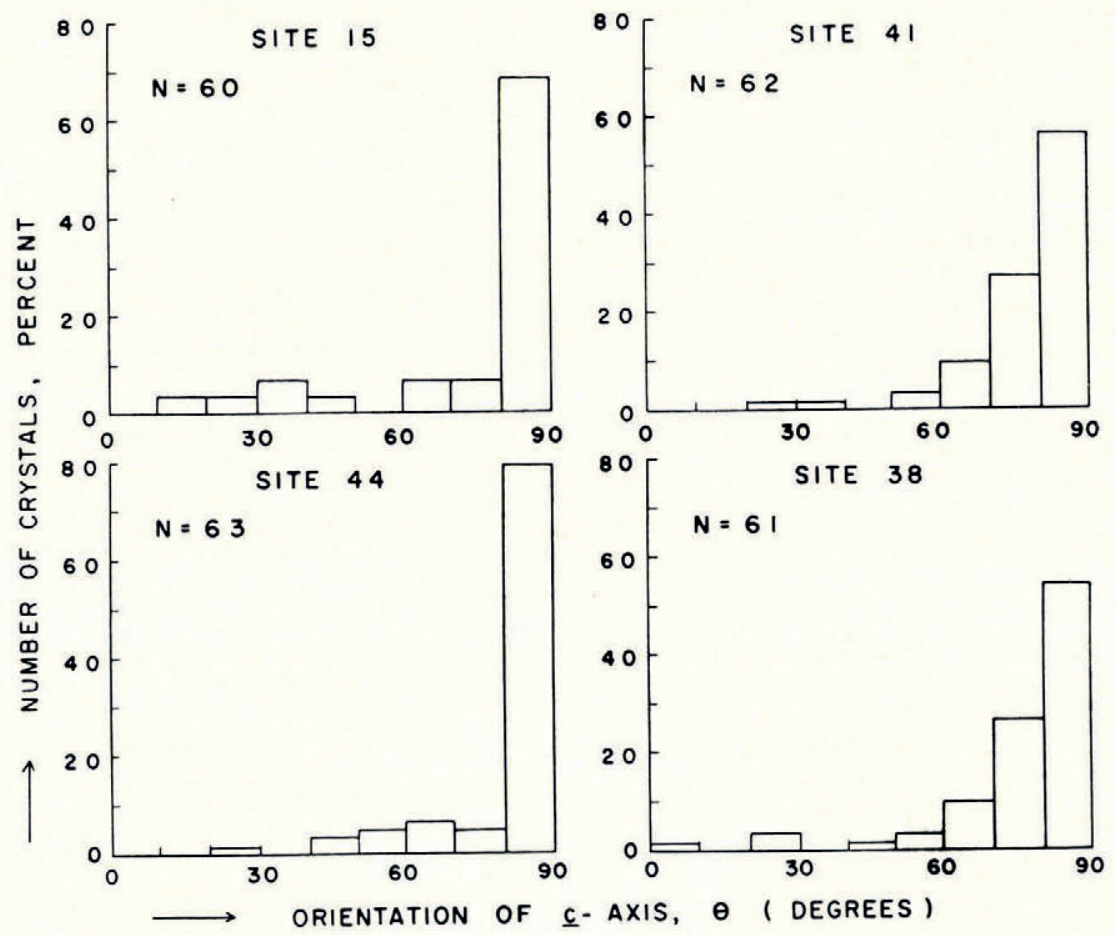

Fig. 19. Histograms of the c-axis orientation of the surface ice at four different sites

of $c$-axis orientation. The orientation of the $c$-axis, $\theta$, is taken as the deviation of the $c$-axis from the normal to the water surface. The ice with predominantly vertical $c$-axes could not be found even in the surface layer of the ice (Fig. I9). The ice with vertical $c$-axes was observed in only $\mathrm{I}-2$ per cent of the total number of grains in the surface layer above $30 \mathrm{~cm}$. depth. From the features of the profiles of the $c$-axis orientations, the ice at Peters Lake in I 962 had a predominantly horizontal $c$-axis orientation, and this was uniform all over the surface of the lake.

\section{(c) Grain-size}

As is shown in Figures 6-18, grain-size increases with the depth of ice. The increase in grain-size is much more enhanced in a vertical direction in contradistinction to a horizontal direction, because of the characteristic nature of lake ice. Grain length in a vertical direction was about $2-5 \mathrm{~cm}$. in the surface layer with an increase to about 10 times as long $(30-50 \mathrm{~cm}$.) near $100 \mathrm{~cm}$. depth. The average grain-size at various depths below the surface was obtained by counting the number of grains in horizontal sections. The size ranged from $0.07 \mathrm{~cm} .^{2}$ at the surface to $5.4 \mathrm{~cm} .^{2}$ at I $00 \mathrm{~cm}$. depth. A fairly good correlation between grain area and 
the depth of ice was obtained from the surface to about $100 \mathrm{~cm}$. depth as is shown in Figure 20. This can be expressed by the formula

$$
S=0 \cdot 07 \exp (0 \cdot 044 d),
$$

where $S$ is the grain area in $\mathrm{cm}^{2}$ and $d$ is the depth of ice in $\mathrm{cm}$. This relationship is no longer applicable below roo $\mathrm{cm}$. depth. The appearance of the change in grain-size at various depths can be seen in Figures 10 to 13 , and 17 and 18 , whose numbers are listed in Figure 20.

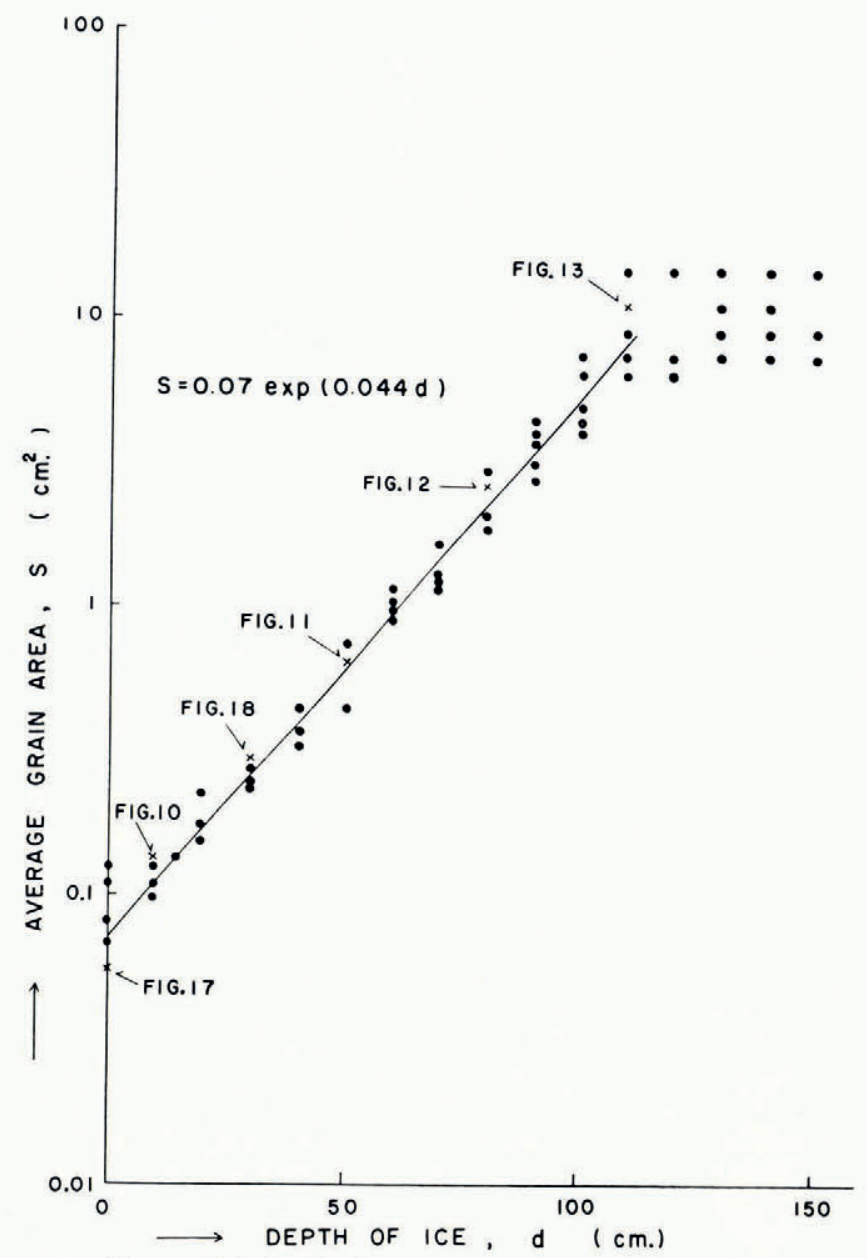

Fig. 20. Relationship between grain area and the depth of ice

No difference in ice structure was noticed between Peters and Schrader Lakes during the present investigation.

\section{(d) Ice of radial structure}

Ice cores taken from refrozen holes, where the entire thickness of the ice was drilled through, showed a beautiful radial structure in horizontal cross-section as is revealed in Figures 22 and 23. These figures depict upper and lower parts of the cores whose vertical sections are shown in Figure 2 I. The radial lines in the ice undoubtedly show the grain boundaries, and this ice is characterized by a fine central tube. This must have been formed 
during preparation of the thin sections, because the grain structure at the centre of the core is very fine and quite different from that at the periphery as can be noticed in Figure $2 \mathrm{I}$. The increase in grain-size with the depth of ice can be seen even over a $10 \mathrm{~cm}$. difference in depth in this peculiar structure of the ice.

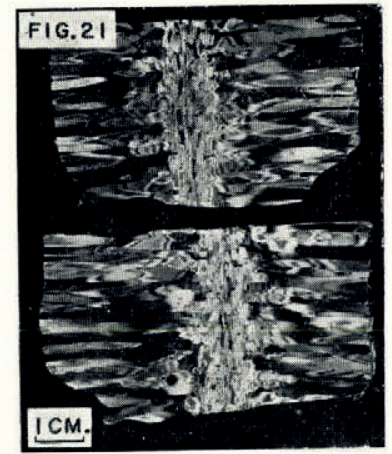

Fig. 2I. Vertical sections of ice with a radial structure; under crossed folaroids
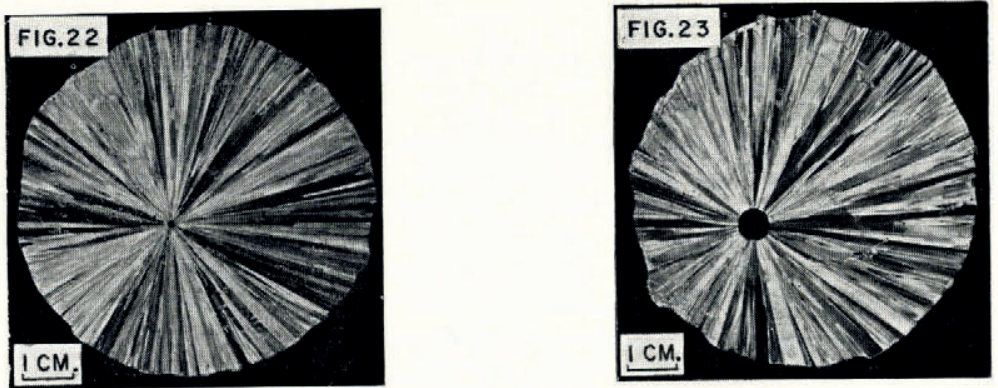

Figs. 22 and 23. Horizontal sections of ice with a radial structure; under crossed polaroids

Ice with a radial structure and characterized by a narrow tube at the centre was found in the ice at ice island T-3 (Muguruma and Higuchi, 1963). Most of the radial lines in the ice were found to be boundaries between single crystals. The size of a single crystal was more than $50 \mathrm{~cm}$. in its greatest dimension. The origin of this peculiar pattern in the ice was considered to be the result of the freezing of water in a tunnel. Ice with a radial structure, observed in a refrozen ice hole at Peters Lake, showed in miniature the same type of ice as that observed at $\mathrm{T}-3$. The speculation offered in the previous work of Muguruma and Higuchi (1963) is clearly sustained by the present study.

\section{Impurity along Grain Boundaries}

Though it was desirable to devise some more sensitive means of detecting any trace of impurity in grain boundaries, the measurement was limited only to electrical conductivity of fresh melt water from the ice. The electrical conductivity was measured by an alternating current Wheatstone bridge between platinum-plated electrodes immersed in water in a plastic container cell of $18 \cdot 5 \mathrm{~cm} .^{3}$. Bulk ice of about $500 \mathrm{~cm} .{ }^{3}$ was subjected to melting by the radiation from an infra-red lamp. At first, the ice block was rinsed with water which had been repeatedly purified with an ion exchange resin such that the specific conductivity of the melt water in the containers would be $0 \cdot 5^{-0} \cdot 8$ micromho $/ \mathrm{cm}$. The specific electrical conductivity of the purified water was always about 0.5 micromho $/ \mathrm{cm}$. Ice samples of a pyramidal shape 
were prepared so that the melt water would drop into the container without contamination. The samples were supported by a plastic ring in such manner as to make the contact area between the sample and the support small enough to avoid any contamination of the melt water. Thus, the measurement was made repeatedly, changing the melt water in the container each time. About ro measurements could be done with each sample. After ten measurements the candling of ice crystals was so enhanced as to cause separation into individual candles, and the sample could no longer be supported by the ring.

Since melting started chiefly along the grain boundaries, initial melt water was expected to contain much more impurity than the last melt water. It is considered that the melting of crystals themselves rather than the melting of the grain boundaries might be pronounced near the end of the melting process. The results of tests on ice from four different sites are shown in Figure 24. Solid lines in that figure indicate the curve obtained for the surface ice layer which contains many grains, and dotted lines show the curve obtained at $30-40 \mathrm{~cm}$.
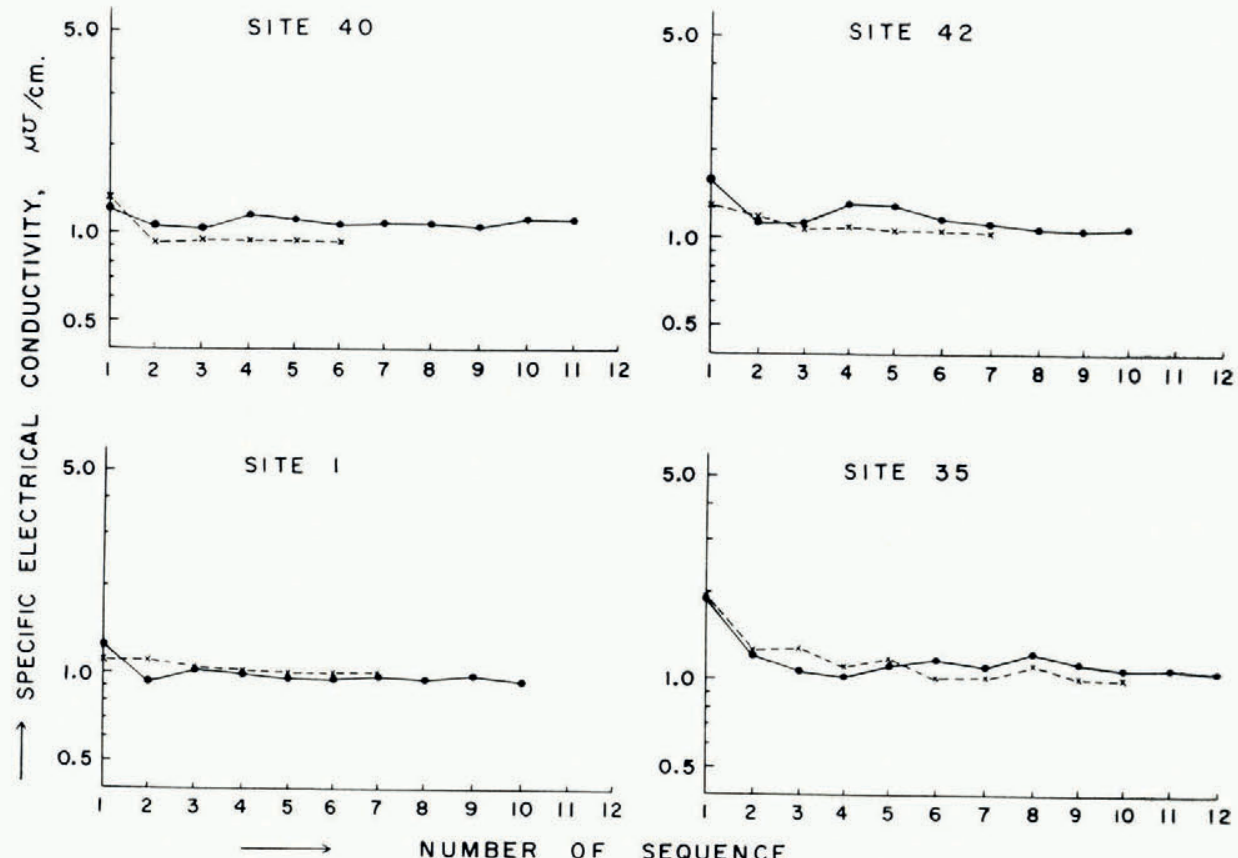

Fig. 24. Change of specific electrical conductivity in an ice sample, using the ice samples from sites $4^{\circ}, 4^{2}, I$ and 35

depth at sites 40 and 42 , and at $140-150 \mathrm{~cm}$. depth at sites I and 35 . All the curves have a tendency to decrease from the first to the second in the sequence number. This shows that the initial melt water contains impurity from the boundaries.

However, it was observed that the melting of boundaries was most pronounced between the third and sixth in the sequence number under the test conditions. From this fact a peak in the curve was expected between these numbers in the sequence. Such a peak was also expected to be less prominent in the crystals which consisted of a small number of grains, but Figure 24 shows that the results could not substantiate any such expectation. The data for measurements of specific electrical conductivity with respect to grain number are summarized in Figure 25. The values of conductivity in Figure 25 were determined from several measurement values which agreed fairly well with each other. No correlation between grain number and impurity content was detected. Specific electrical conductivity of the ice at Peters Lake 
ranged from 0.8 to $\mathrm{I} \cdot 4$ micromho/ $\mathrm{cm}$., which is of nearly the same order of magnitude as that of the ice of Mendenhall Glacier, Alaska (I micromho/cm.) (Higashi and others, in press).

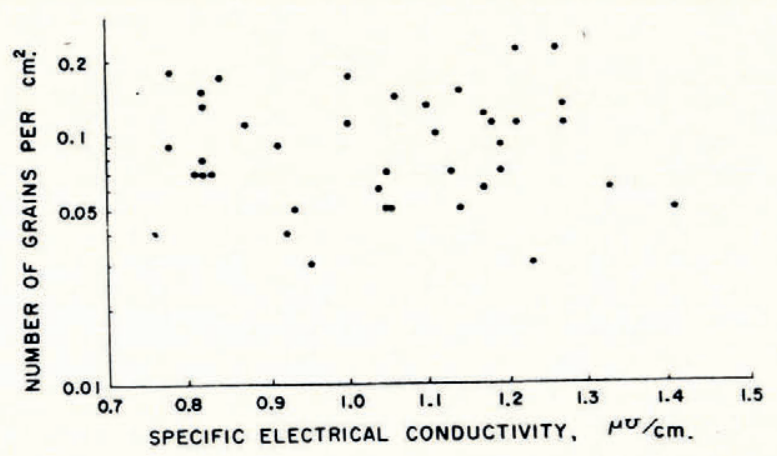

Fig. 25. Average specific electrical conductivity with respect to number of grains

\section{Investigation at Lake Nukabira}

\section{(a) Description}

Lake Nukabira is an artificial lake impounded by a dam for the purpose of producing hydro-electricity. This lake is located in the central part of Hokkaido (Fig. 26). As can be seen in Figure 26 , the lake lies within a fairly steep-sided valley in the southern area, while it is surrounded by gentle slopes in the northern area. Wind blows either from a northerly or southerly direction along the length of the lake. There is a long and narrow bay at the south end of the lake, where there is relatively little wind. The differences between the topography around the main area of the lake and the bay at the south end are believed to affect the appearance of the ice structure, because of the respective effects of wind action.

\section{(b) Ice structure}

Ice samples were obtained at 6 sites (Fig. 26). At all sites except site 5 the ice is granular in the surface layer with candle ice below it. Examples of this structure are shown in Figures 27 to 29. In Figures 27 and 29 are shown horizontal sections of ice from the surface and the bottom respectively, and a vertical section from the bottom is shown in Figure 28. The ice from the surface layer is granular (Figs. 27 and 28) and the appearance of the vertical and horizontal sections is similar. Granular ice in the surface layer is a common structure of lake ice; it is formed by the freezing of deposited snow soaked in water. This kind of structure was not found in the ice at Peters Lake and this fact shows that the water level of the lake did not increase after the formation of the ice. The change in water level at Lake Nukabira would be considerable. The thickness of ice at different sites is summarized in Table I.

$\begin{array}{crcc}\text { TABLE I } & \\ \text { Site number } & \begin{array}{c}\text { Thickness of ice } \\ \text { Candle ice } \\ \text { cm. } \\ \text { cm. }\end{array} & \begin{array}{c}\text { Total ice } \\ \text { thickness } \\ \mathrm{cm} .\end{array} \\ \text { I } & 7 & & \\ 2 & 2 & 15 & 22 \\ 3 & 11 & 10 & 12 \\ 4 & 0 & 16 & 27 \\ 5 & 3 & 20 & 20 \\ 6 & 9 & 17 & 20 \\ & & 8 & 17\end{array}$


The $c$-axis orientation was determined by the same procedure as described already. At sites I and 2 all the candle ice showed predominantly horizontal $c$-axes and its grain-size was quite small. The numerous short bars which can be seen in Figure 29 characterize the ice with horizontal $c$-axes at site 2. Figure 30 shows the carbon rubbing from an etched ice surface, proving the presence of ice with horizontal $c$-axes at site I and the increase of grain-size with ice depth. Ice with vertical $c$-axes at site 5 is shown in the rubbing of Figure 3 r. Numerous

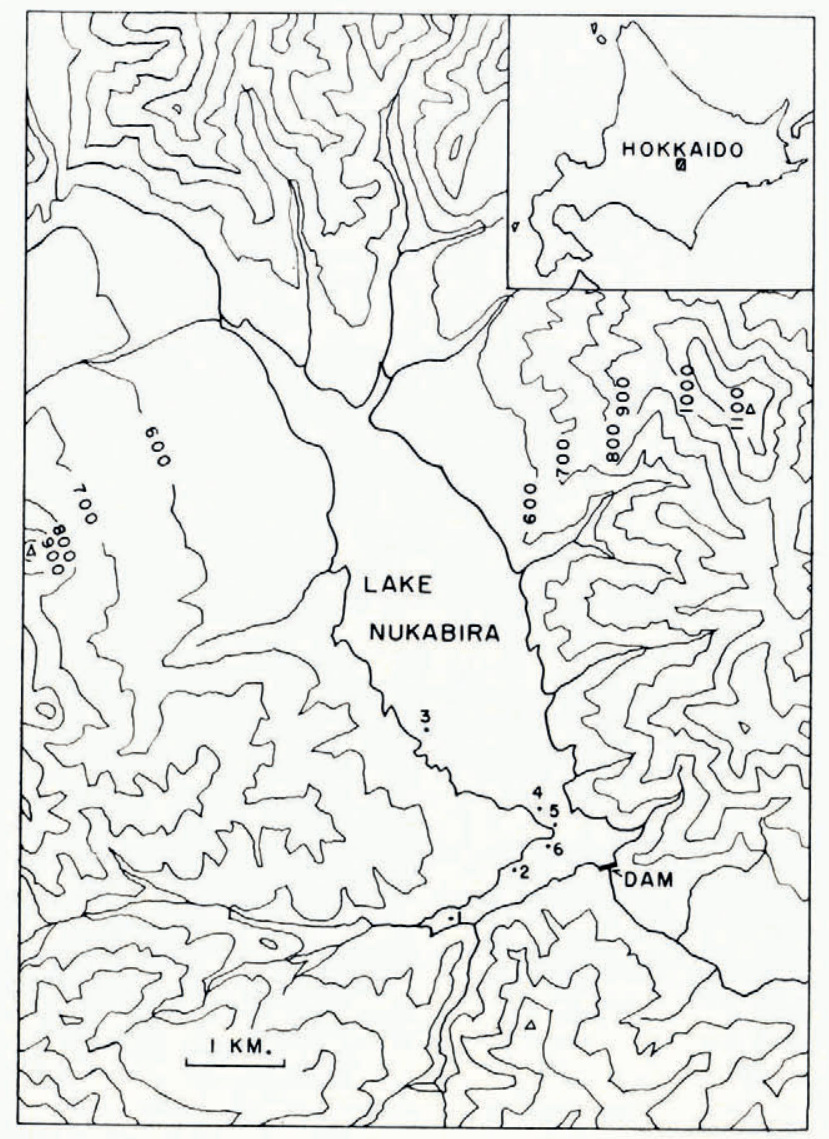

Fig. 26. Map of Lake Nukabira showing the locations where ice samples were obtained

short horizontal bars seen in the vertical section in Figure $3 \mathrm{I}$ are the marks of Tyndall figures. The many hexagonal figures seen in the horizontal section in Figure $3 \mathrm{I}$ are also the marks of Tyndall figures. Comparing these two sections, one sees that the orientation of the $c$-axes of the crystals in Figure $3 \mathrm{I}$ is perfectly vertical. The $c$-axis vertical ice was found not only at site 5 , but also at sites 3,4 and 6 .

The statistical distribution of horizontal and vertical $c$-axes at four different sites is shown in Figure 32 . The ice from the bay has predominantly horizontal $c$-axes, while the ice with predominantly vertical $c$-axes occurs in the main part of the lake. It was considered that wind action was responsible for the formation of the two types of ice. The grain-size of vertical $c$-axis ice was much larger than that of the horizontal $c$-axis ice, as can be seen by comparing Figure 30 with Figure 31. 


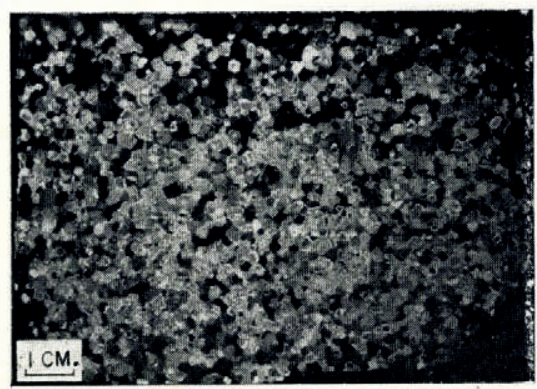

Fig. 27. Horizontal section of granular ice in the surface layer of ice at site 2; under crossed polaroids

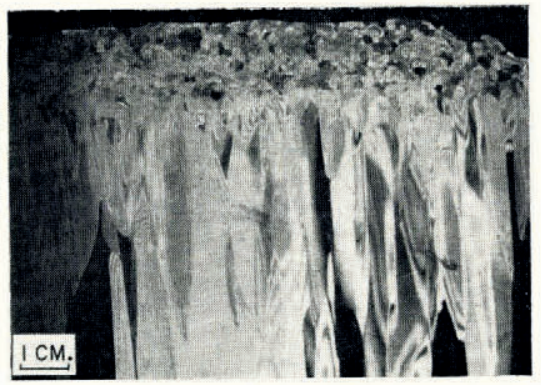

Fig. 28. Vertical section of ice at site 2 showing granular and candle ice; under crossed polaroids

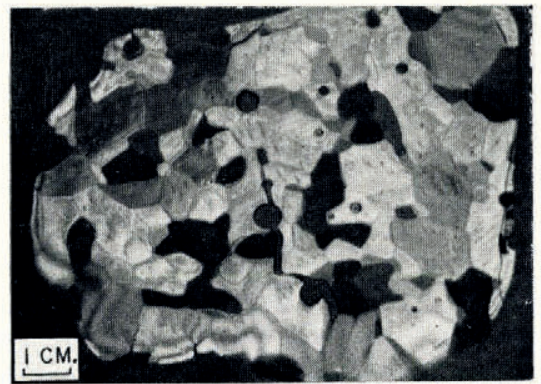

Fig. 29. Horizontal section of ice with horizontal c-axes at the bottom of the ice at site 2. Numerous short bars show Tyndall figures; under crossed polaroids

\section{(c) Impurity measurement}

The same procedure as described previously for the measurement of impurity was followed. Since the ice thickness was not great enough to enable separation into two layers in preparing the samples for measurement, relationship between grain-size and impurity content at any one site could not be examined. It was expected, however, that the difference in grain-size depending upon both the location of the sampling site and the types of ice would result in some difference in impurity content.

Typical results are shown in Figure 33. A peak in the curve is clearly observable for the fine-grained crystals at site 2 but not for coarse-grained crystals at site 3 . As was described in detail previously, a peak appeared between the third and sixth sequence numbers. This. shows clearly the impurity from boundaries. The curve for site 3 shows the same features as. that of the ice from Peters Lake. 


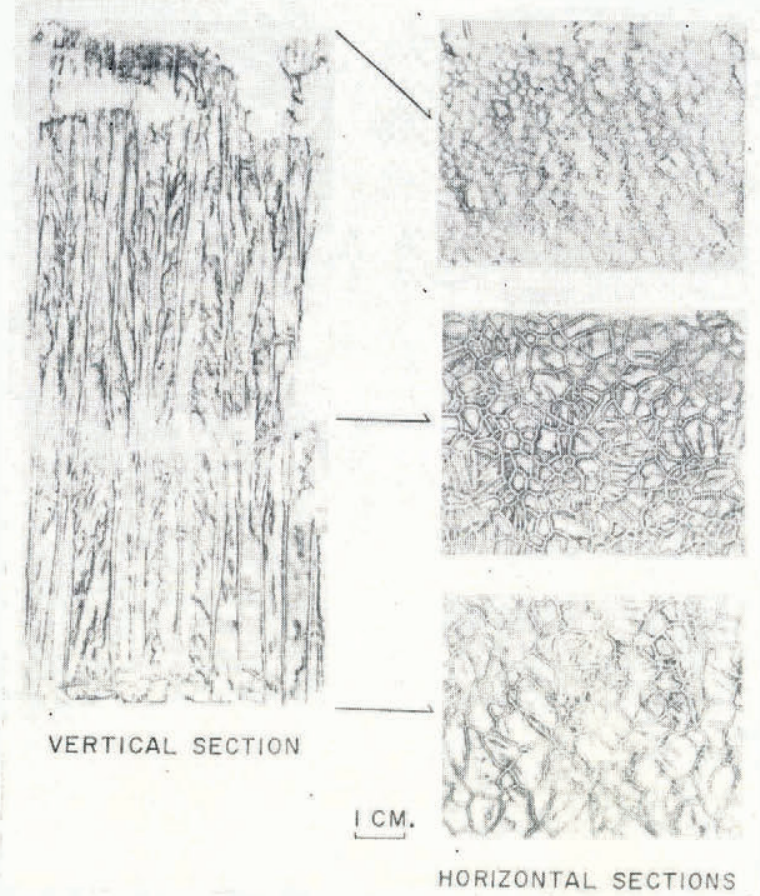

Fig. 30. Carbon rubbings of vertical and horizontal sections of ice with horizonlal c-axes at Site I, Lake Nukabira, showing grain boundaries, Tyndall figures and increase in grain-size with depth
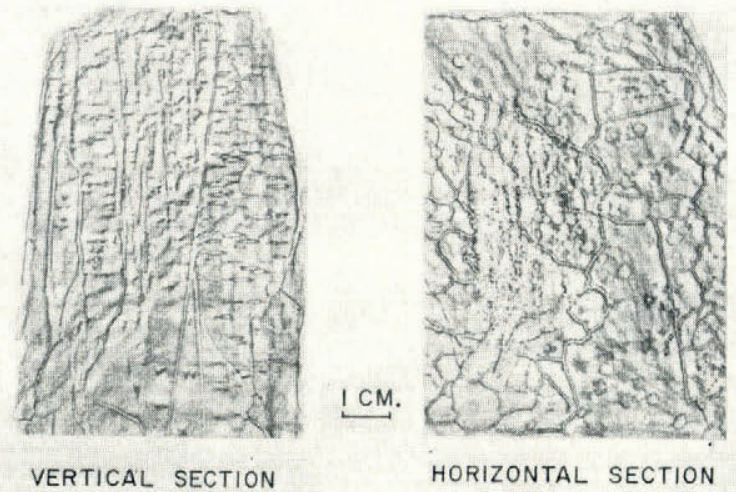

Fig. 3I. Carbon rubbings of vertical and horizontal sections of ice with vertical c-axes at site 5 , Lake Nukabira, showing grain boundaries and Tyndall figures. Horizontal section was taken at the bottom of the ice

\section{Discussion}

\section{(a) Ice structure}

The present investigation supports the idea proposed by Knight (1962) explaining the causes of two types of ice, i.e. that wind is the main factor. The fact that the ice structure at Peters Lake in 1962 was quite different from that in r 96 I (Knight, I 962 ) and in r 959 (Barnes, I959) suggests the great difference in weather conditions at an early stage in the freezing of the lake water. The uniform ice structure at Peters Lake suggests that break-up of the initial ice skim did not take place during that period, i.e. wind was very slight. 

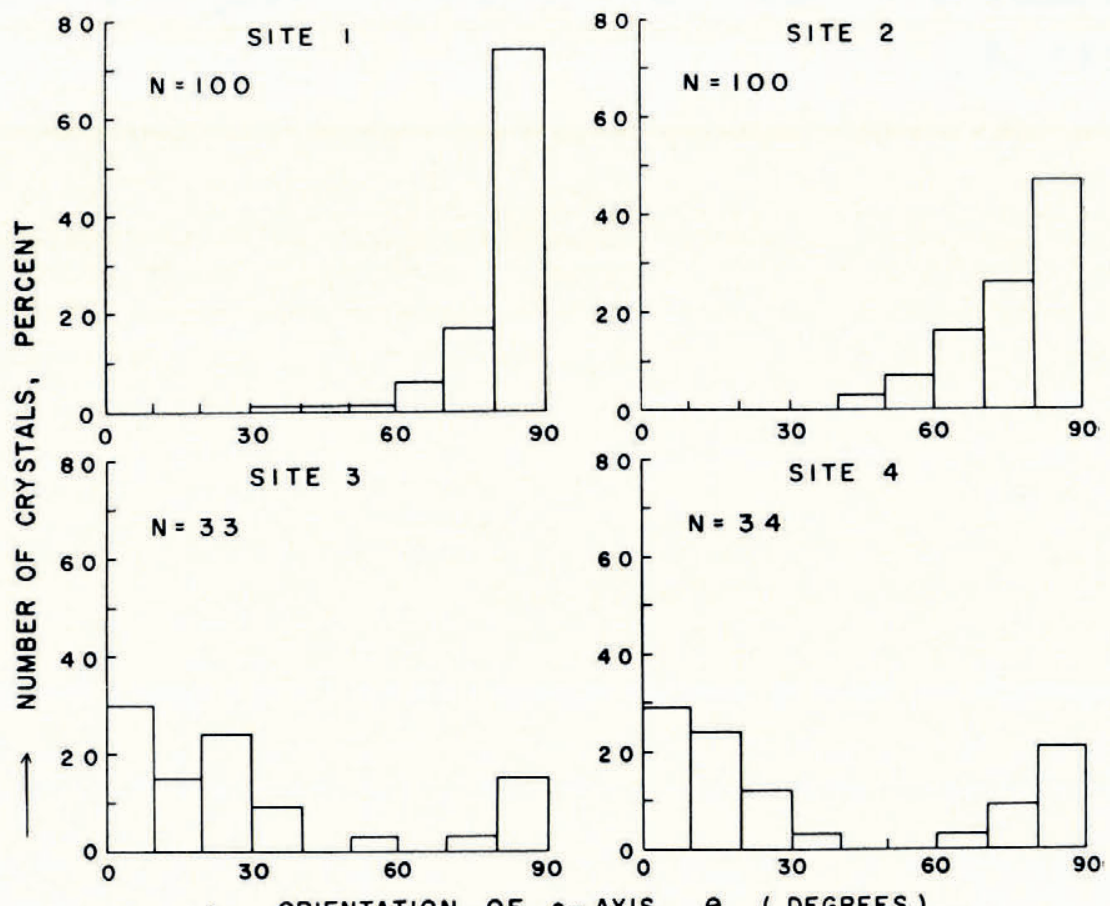

Fig. 32. Histograms of the c-axis orientation at four different sites
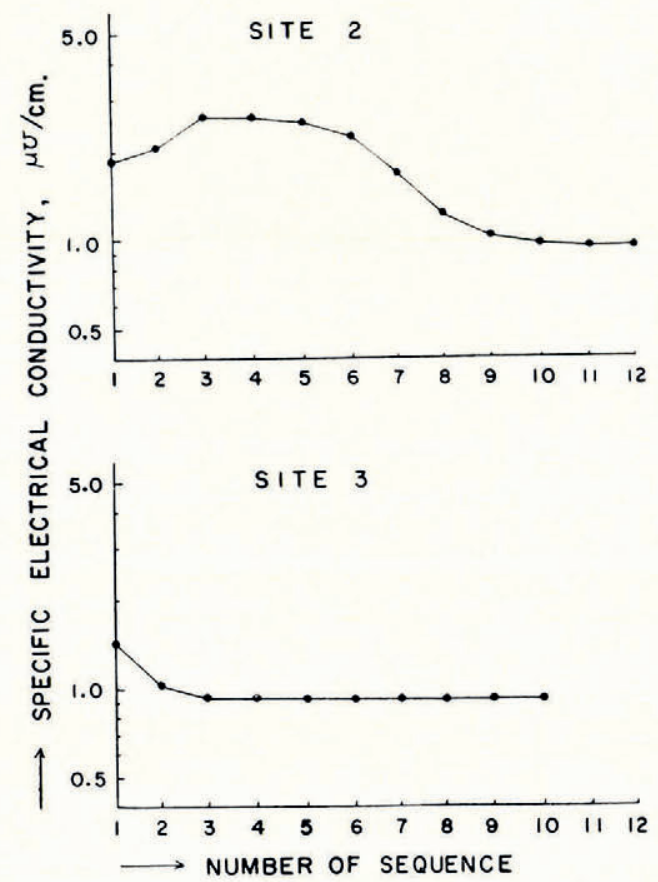

Fig. 33. Change of specific electrical conductivity in an ice sample, using the ice samples from sites 2 and 3 
The difference in grain-size in the surface layer and the $c$-axis orientation would depend upon the weather conditions during an early stage in the freezing of lake water. If lake water is frozen on a very calm day and under slight temperature gradient conditions, and the initial ice skim does not break up, the ice would start with vertical $c$-axes and show coarse grain. The vertical $c$-axis ice with coarse grain observed in the main area of Lake Nukabira would not belong to this category. Though wind conditions were much calmer in the bay of Lake Nukabira than in the main area of the lake, the ice in the bay had horizontal $c$-axes and was fine-grained.

The break-up of the initial ice skim is considered to be an important factor in the formation of the two types of ice (vertical $c$-axis ice and horizontal $c$-axis ice). Wind-broken initial ice skim would push pieces of broken ice towards a coast, and the ice would become jammed. Lyons and Stoiber ( 1962 ) have pointed out that the thickness of the supercooled water layer and the greater velocity of crystallization in the basal plane of the ice are among the factors influencing preferred orientation of the $c$-axis. Under normal weather conditions the orientation of $c$-axes in most types of lake ice would be predominantly horizontal as is noted in the ice of Peters and Nukabira Lakes. Pieces of broken ice slabs, pushed towards a coast by the wind, would be jammed just like a pack of cards in a horizontal direction. Thus, initial $c$-axis horizontal ice could become the $c$-axis vertical ice in the area of jammed ice, mostly occupying a shore zone.

(b) Decay of snow and ice at Peters Lake

Minute efflorescences of rock particles were observed on and in the deposited snow on the lake (Fig. 34). They were naturally wind-blown particles and distributed over almost the

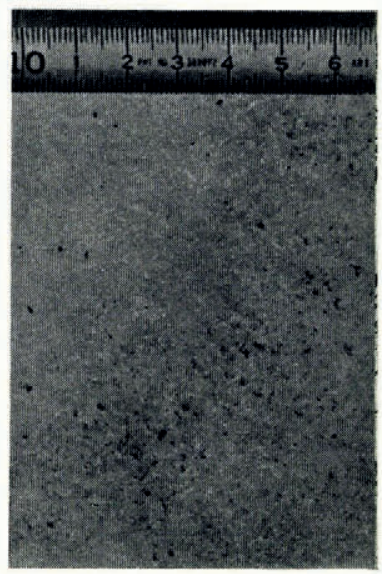

Fig. 34. Naturally wind-blown rock particles observed on and in redeposited snow at Peters Lake

whole central area of the lake between the east and west shores. A large number of particles was observed at the southern end of the lake. The maximum quantity of particles measured was about $0.05 \mathrm{~g} . / \mathrm{cm} .{ }^{3}$ in area "C'" and $0.02 \mathrm{~g} . / \mathrm{cm} .^{3}$ in area "D" of Figure 5.

From the artificial acceleration of snow melting by scattering soil particles on a snow surface (Magono and Kumai, I954) it is known that a very small amount of soil is enough to accelerate melting. A quantity of $0.0 \mathrm{I} \mathrm{g} . / \mathrm{cm} .{ }^{3}$ can double the rate of melting. If such a small quantity of soil particles could double the rate of melting, the rock particles observed at Peters Lake must considerably accelerate the decay of snow and ice.

Taking into account the differences in ice thickness and the distribution of rock particles 
over the whole area of Peters Lake, it is considered that the ice along the east shore area of the lake north of the camp (area " $B$ " in Figure 5) would be stronger and last longer than the ice in other areas of the lake.

\section{Acknowledgements}

The field investigation reported in this paper was supported by the Arctic Institute of North America under contract with the Geophysics Research Directorate, Air Force Cambridge Research Laboratories. Professor Ukichiro Nakaya directed the research project, but in April 1962 while the authors were in Alaska he unfortunately died. The authors wish to express their sincere sorrow over Professor Nakaya's death and their grateful thanks to him for guidance in planning the work. We are indebted to Dr. Max C. Brewer, Director of the Arctic Research Laboratory at Point Barrow, for kindly arranging the research programme and to Mr. R. F. Riddell for his valuable assistance in managing the camp at Peters Lake. Indebtedness is acknowledged to Dr. A. Higashi for his direction of this project after Professor Nakaya's death and for his criticism during preparation of the manuscript.

MS. received 7 May $19^{6} 3$

\section{R E F E R E N CES}

Barnes, D. F. 1959. Preliminary report at Lake Peters, Alaska: ice studies. (In Bushnell, V. C., ed. Proceedings of the second annual Arctic planning session, October 1959. Bedford, Mass., Geophysics Research Directorate, U.S. Air Force Cambridge Research Center, p. $102-10$. (GRD Research Notes, No. 29.))

Higashi, A., and Sakai, N. 196r. Movement of small angle boundary in ice crystal. Journal of the Faculty of Science, Hokkaido University, Ser. 2, Vol. 5, No. 5, p. $221-37$.

Higashi, A., and others. In press. Glaciological investigation of the Mendenhall Glacier, Alaska, by A. Higashi, S. Hashimoto, K. Itagaki, H. Shimizu, S. Kumano, T. Takahashi and K. Kikuchi. Arctic.

Knight, C. A. 1962. Studies of Arctic lake ice. Journal of Glaciology, Vol. 4, No. 33, p. 319-35.

Lyons, J. B., and Stoiber, R. E. 1962. Orientation fabrics in lake ice. Fournal of Glaciology, Vol. 4, No. 33, p. 367-70.

Magono, C., and Kumai, M. 1954. Basic studies on acceleration of snow melting. II. Institute of Agricultural Physics, Sapporo. Research Paper, Vol. 3. [Text in Japanese.]

Muguruma, J., and Higuchi, K. ${ }_{1963}$. Glaciological studies on ice island T-3. Journal of Glaciology, Vol. 4, No. 36,

p. 709-30.
Nakaya, U. 1958 . Mechanical properties of single crystals of ice. U.S. Snow, Ice and Permafrost Research Establishment. Research Paper 28.

Nakaya, U. 1959. Future plans for oceanographic and glaciological studies on T-3. (In Bushnell, V. C., ed. Proceedings of the second annual Arctic planning session, October 19.59. Bedford, Mass., Geophysics Research Directorate, U.S. Air Force Cambridge Research Center, p. 43-44. (GRD Research Notes, No. 29.)) 